\title{
A1- and A2-Milk and Their Effect on Human Health
}

\author{
Shehadeh Kaskous \\ Department of Research and Development, Siliconform, Türkheim, Germany \\ Email: shehadeh.kaskous@yahoo.de
}

Received:12 March 2020; Accepted: 3 April 2020; Available online: 30 April 2020

\begin{abstract}
Milk proteins are a heterogeneous group of polymeric compounds that have a wide range of different molecular structures and properties. They occur as caseins, whey proteins, enzymes, minor proteins and nitrogen compounds. Caseins constitute about $80 \%$ of the total proteins of cow's milk. $\beta$-casein is an important part of the caseins, which makes up about $37 \%$ of the total caseins. Within $\beta$-casein, there are a number of variants which are genetically determined. However, there are thirteen genetic variants of $\beta$-casein found in cow's milk. A1 and A2 are the most common variants, which are called A1 $\beta$-casein (A1-milk) and A2 $\beta$-casein (A2-milk). The only difference between A1- and A2-milk is a difference in the 67th amino acid in the chain. At this position, A2-milk has a proline amino acid, while A1-milk has histidine amino acid. Several studies have reported that cow's milk with a dominant or singular A2-milk may be healthier than A1-milk. These studies are based on digestion of A1milk which lead to release $\beta$-casomorphin-7 (BCM-7). Subsequently increase inflammation, Type-1-diabetes, heart disease, autism, gastrointestinal discomfort and other disease in the consumer. For this reason, there is a growing global interest in A2-milk. In conclusion, the effects of A1-milk compared to A2-milk on human health show mixed results. On the basis of the available results, we cannot conclusively assess the health effects of A1milk and A2-milk. Therefore, further investigations are needed.
\end{abstract}

Keywords: Cow; Milk; A1-milk; A2-milk; $\beta$-Casein; $\beta$-casomorphin-7; Human disease.

\section{Introduction}

Every day, billions of people around the world consume milk and milk products, which play a key role in healthy human nutrition and development throughout life. However, the role of milk and dairy products in human nutrition has been increasingly discussed in recent years [1, 2]. Milk is a complex food containing numerous nutrients (Tab. 1) and it makes a significant contribution to meeting the body's needs for fat, proteins, sugar, minerals and vitamins. On the other hand, milk does not contain enough iron and folate to meet the needs of growing infants, and the low iron content is one reason that animal milk is not recommended for infants younger than 12 months.

Tab. 1. Average composition of different milk lactating animals [3-6].

\begin{tabular}{llllll}
\hline $\begin{array}{l}\text { Lactating } \\
\text { animals }\end{array}$ & $\begin{array}{l}\text { Dry Matter } \\
\%\end{array}$ & $\begin{array}{l}\text { Lactose } \\
\%\end{array}$ & $\begin{array}{l}\text { Protein } \\
\%\end{array}$ & $\begin{array}{l}\text { Fat } \\
\%\end{array}$ & $\begin{array}{l}\text { Ash } \\
\%\end{array}$ \\
\hline Cow & 13 & 4.9 & 3.4 & 4.0 & 0.7 \\
Goat & 13.2 & 4.1 & 3.4 & 3,5 & 0.8 \\
Sheep & 19.3 & 4.8 & 5.5 & 7.4 & 0.9 \\
Buffalo & 17.2 & 4.8 & 4.2 & 7.6 & 0.8 \\
Camel & 10.6 & 4.0 & 2.3 & 3.5 & 0.7 \\
\hline
\end{tabular}

Currently, dairy cows are the main source of milk production in the world. However, milk from a range of other animal species is also consumed. Most of the constituents in milk do not work in isolation, but rather interact with other constituents. Often, they are involved in more than one biological process, sometimes with conflicting health effects. Thus, it's possible that there is a connection between high dairy consumption and some diseases such as cardiovascular disease, Type-1-diabetes, Gastrointestinal disease, Autism, prostate cancer and other diseases [2, 7, 8]. There are also reports suggesting that peptides in the milk may have a negative effect on human health [9]. For example, when digesting milk with a bad $\beta$-casein variant, BCM-7 is released [10], which may be responsible for milk protein intolerances. It has also shown that BCM-7 can be found in raw cow's milk [11]. The presence of BCM-7 in raw cow's milk is probably related to the increase of somatic cell counts (SCC) in milk [9]. SCC in milk are a normal phenomenon and their count increases dramatically during subclinical or clinical mastitis. 
Increasing SCC is associated with increasing proteolysis of caseins. Therefore, the proteolytic activity in animals having a high SCC may contribute to the release of BCM-7. In the following, $\beta$-Casein variants, properties, structure, occurring in dairy cows and their influence on human health are presented and discussed.

\section{What is A1-and A2-milk?}

Milk proteins are a heterogeneous group of polymeric compounds that have a wide range of different molecular structures and properties. They occur as Caseins, whey proteins, proteins of the fat globule membrane, enzymes, minor proteins and nitrogen compounds [3, 12, 13] (Tab. 2).

Tab. 2. Compositional protein quality in cow's milk according to Barth and Behnke [14] with some changes.

\begin{tabular}{lll}
\hline Protein components & Protein subclasses & Concentrations (g/kg) \\
\hline Caseins & $\alpha_{\mathrm{s} 1}$-casein (A, B, C, D, E) & 10.3 \\
& $\alpha_{\mathrm{s} 2}$-casein (A, B, C, D) & 2.7 \\
& $\beta$-casein (A1, A2, A3, B, C, D, E, F, G, H $\left.{ }^{1}, \mathrm{H}^{2}, \mathrm{I}\right)$. & 9.6 \\
& $\mathrm{k}$-casein (A, B) & 3.5 \\
& $\gamma$-Casein & 0.8 \\
Whey proteins & $\alpha$-Lactalbumin (A, B, C) & 1.2 \\
& $\beta$-Lactoglobulin (A, B, C, D, E, F, G) & 3.4 \\
& Serum albumin & 0.4 \\
& Immunoglobulins (A, G1, G2, M, E) & 0.7 \\
& Lactoferrin & 0.1 \\
Enzymes & Transferrin & 0.1 \\
Peptide hormone & Other minor proteins & 0.1 \\
Non-protein-nitrogen & Lysozyme, lactoperoxidase, and 60 others & traces \\
& Prolactin, growth hormone, insulin growth factor (IGF) & traces \\
& Urea, creatine, creatinine, peptide, uric acid, hippuric, orotic & 1.1 \\
\hline
\end{tabular}

It is known that casein represents about $80 \%$ of total protein in cow's milk [3, 15]. Beta-casein is a second important part of casein, which constitutes up to $45 \%$ of bovine casein [16]. Within $\beta$-casein, there are a number of variants which are genetically determined [17]. The first evidence of genetic polymorphism in $\beta$-casein came from Aschaffenburg [18] while studying milk from Jersey and Guernsey cows. It was reported that $\beta$-casein existed as three polymorphs A, B and C. Subsequently, it was discovered that $\beta$-casein A could be separated into three additional variants [19]. It is known as $\beta$-casein $A^{1}, A^{2}$ and $A^{3}$. After that, Eigel et al., [20] described seven genetic variants of $\beta$-casein (A1, A2, A3, B, C, D and E). The studies by Farrell et al., [17] and Kaminski et al., [12] have shown that, there are twelve genetic variants of $\beta$-casein found in cow's milk $\left(A^{1}, A^{2}, A^{3}, B, C, D, E, F, G, H^{1}, H^{2}\right.$ and I). Clemens [21] reported that there are thirteen genetic variants of $\beta$-casein in dairy cattle. But, A1, A2 and B milk are the most common forms among dairy cattle [7, 22]. Therefore, it is also called A1-milk and A2-milk. A1milk has been implicated in the literature in relation to human disease as a potential etiological factor in type-1diabetes mellitus, ischemic heart disease, schizophrenia, and autism [10]. Another variant of A2-milk has not been implicated in these diseases [23].

\section{Biochemical structure of A1 $\beta$-casein and A2 $\beta$-casein}

Beta-casein is a 209 chain amino acid protein, and the A1 version has one amino acid that is different from A2 $[24,25]$. A1 has a histidine at position 67 that allows an enzymatic cleavage to occur releasing a 7 amino acid called BCM-7 [7, 10, 26]. The A2 variant has a proline at position 67 so that BCM-7 is not released [25] (Fig. 1).

\section{Cow breeds and type of milk}

As we know, the casein proteins make up about $80 \%$ of milk protein and one of these is $\beta$-casein, of which the two most common forms are A1 and A2. Originally, all milk was A2, but due to a genetic mutation at some point, the A1 form appeared [27]. That means the genetic mutation changed the amino acids from proline to histidine based and gradually became the prevalent form of beta casein. The modern dairy breeds still produce some A2milk although the percentage varies between breeds. The frequency of the A2 allele appears to be around $60 \%$ in Holsteins. This means that about 35\% of Holstein Friesian produce A2-milk, 48\% produce a mix of A1-and A2milk, and 16\% produce A1-milk [28]. Therefore, Holstein Friesian has the lowest proportion of A2-milk in relation 
to other breeds. Brown Swiss and Fleckvieh have the proportion at around 65\%, which produce A2-milk [7, 29]. The Guernsey has the highest proportion of the A2-milk gene at over 90\% [28]. All the other main dairy breeds have about 50\%. Thus, most cows produce a combination of these two proteins A1-and A2-milk [12]. However, A1-milk is absent in purebred Asian and African cattle [25]. Similarly, the presence of A1-milk in other mammalian species is either absent or extremely rare [24,30]. The avoidance of A1-milk is feasible within dairybased diets through the consumption of sheep, buffalo and goat milk or through the consumption of bovine milk from the native Asian and African bovine breeds [25]. However, the consumption of milk from European-type cattle is possible, which is free of the A1-milk. Such herds are being developed in many countries [7].

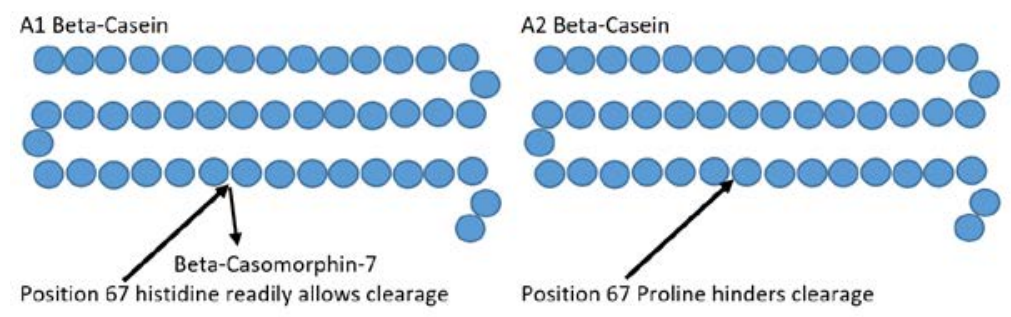

Figure .1. A1 and A2 Beta-Casein

\section{Which diseases can occur after consumption of cow's milk with A1 or A2?}

The controversy surrounding A1 versus A2 relates to the digestion of $\beta$-casein. When proteins are digested, bioactive peptides can be released [31]. A peptide is simply a small chain of amino acids. This peptide called BCM-7 is a seven amino acid peptide that is thought to be much more commonly released when A1-milk is digested than when A2-milk is digested [9, 32-34]. BCM-7 has opioid-like properties that are suggested to affect up to $25 \%$ of the human population [26, 28, 34]. A few research groups suggest that BCM-7 may be linked to type-1-diabetes, heart disease, infant death, autism, and digestive problems [35-38]. While BCM-7 may affect the digestive system, it's still unclear to what extent BCM-7 is absorbed intact into blood [8]. Studies have shown that BCM-7 is not found in the blood of healthy adults who drank cow's milk, but a few tests indicate that BCM-7 may be present in infants [37-39]. Furthermore, Kost et al., [37] found that breast feeding has an advantage over artificial feeding for infants' development during the first year of life and supports the hypothesis for deterioration of bovine casomorphin elimination as a risk factor for delay in psychomotor development and other diseases such as autism. Therefore, the world health organization (WHO) recommends that infants should be exclusively breast fed for six months and breastfeeding should continue beyond the second year to ensure healthy growth and development [40].

\subsection{Type-1-diabetes}

Type-1-diabetes is a form of diabetes mellitus. It is due to a lack of insulin due to the destruction of insulinproducing $\beta$-cells in the islets of Langerhans of the pancreas by autoimmune processes. The contribution of cow's milk containing A1-milk variant to the development of type-1-diabetes has been controversial for decades [41]. Cow's milk, one of the first foods introduced early to infants, is one such putative environmental factor [42]. Children who have specific human leukocyte antigen genotype (HLA-DR) paired with a greater dietary intake of cow's milk protein may be at an increased risk of developing islet autoimmunity and progression to Type-1diabetes [43]. However, Birgisdottir et al., [36] reported that lower consumption of A1-milk might be related to the lower incidence of type-1-diabetes in Iceland than in Scandinavia. But it was indicated that consumption in young childhood might be of more importance for the development of the disease incidence than consumption in adolescence. Similarly, McLachlan, [35] found that A1-milk consumption correlates strongly with type-1-diabetes incidence in 0-14-year-olds. Elliott et al. [26] indicated that total protein consumption did not strongly correlate with diabetes incidence $(r=+0.402)$, but consumption of the A1-milk variant did $(r=+0.726)$. Even more pronounced was the relation between $\beta$-casein $(\mathrm{A} 1+\mathrm{B})$ consumption and diabetes $(\mathrm{r}=+982)$. Most compelling is the data analysis by Laugesen and Elliott [44] which demonstrated a positive correlation ( $r=0.92)$ between cow's A1-milk supply per-capita and type-1-diabetes in 19 developed countries. This study clearly showed that a higher incidence rate was observed in Finland and Sweden (highest A1-milk consumption/per capita) and low rates have been found in Venezuela and Japan (lowest A1-milk consumption/per capita). In general, many studies have shown that consumption of A1-milk in childhood increased the risk of type-1-diabetes [10, 21, 26, 35, 36, 44] and in lactose intolerant individuals, lactose malabsorption and digestive comfort with lactose-containing milks was improved with milk containing exclusively A2-milk [45].

In addition, studies on animals have shown that no difference between A1-and A2-milk can be detected referring to type-1-diabetes [26, 46-48]. On the contrary, the consumption of A1-milk in genetically susceptible mice 
increases the incidence of type-1-diabetes, which only becomes evident in later generations [41].

\subsection{Heart disease}

Previous studies indicated a correlation between the consumption of the milk protein A1-milk (excluding milk protein in cheese) and ischemic heart disease mortality in West Germany, Toulouse in France and Belfast in Northern Ireland and the value was a $\mathrm{r}^{2}=0.86$ [35]. Similar results have indicated that A1 $\beta$-casein per capita supply in milk and cream was significantly and positively correlated with ischaemic heart disease in 20 countries $[44,49]$. On the contrary, the studies in fifteen asymptomatic participants (six male; nine female) at high risk of developing cardiovascular disease have shown that the supplementation with A1-milk has not any cardiovascular health disadvantage over consumption of A2-milk [50]. In the same way, the studies by Venn et al., [49] showed no evidence that dairy products containing beta-casein A1 or A2 exerted differential effects on plasma cholesterol concentration in humans.

\subsection{Gastrointestinal disease}

There are a number of studies on the impact of A1- or A2-milk on digestive tract health [51, 52]. However, the increasing consumption of dairy products is associated with an increase in the risk of gastrointestinal function [53 -56]. Ho et al., [51] have found that A1-milk led to significantly higher stool consistency values (Bristol Stool Scale) compared with the A2-milk. Furthermore the authors found a significant positive association between abdominal pain and stool consistency on the A1-milk diet ( $\mathrm{r}=0.52)$, but not the A2-milk diet $(\mathrm{r}=-0.13)$. Jianqin et al., [57] reported that the consumption of milk containing both types (A1-milk and A2-milk) was associated with significantly greater post-dairy digestive discomfort symptoms; higher concentrations of inflammation-related biomarkers and BCM-7; longer gastrointestinal transit times and lower levels of short-chain fatty acids. On the other hand, consumption of milk containing only A2-milk did not aggravate post-dairy digestive discomfort symptoms. Other studies in Germany have shown that after the application of A2-milk in 10 people who cannot tolerate A1-milk, have not had gastrointestinal problems [7]. He et al. [52] investigated that milk containing A2milk attenuated acute gastrointestinal symptoms of milk intolerance, while conventional milk containing A1-milk reduced lactase activity and increased gastrointestinal symptoms.

Animal studies have shown that the effect of A1- versus A2-milk on gastrointestinal was directly influenced [56, 58]. Similarly, it has been reported that casein and its derivatives, particularly BCM-7, exert a variety of effects on gastrointestinal function in animals, including reducing the frequency and amplitude of intestinal contractions [53, 59-61]. Interestingly, Barnett et al., [56] also shown in rats that A1-milk feeding relative to A2milk feeding significantly increased the colonic activity of the inflammatory marker myeloperoxidase by $65 \%$, an effect also negated by the opioid blocker naloxone.

In general, it has been shown that the consumption of milk containing A1-milk would lead to systemic inflammation and gastrointestinal motility through the release of BCM-7 [51, 57]. In fact, further animal research and clinical trials is needed to compare disease risks of A1-free versus ordinary milk.

\subsection{Autism}

Autism, also called autism spectrum disorder, is a group of neurodevelopmental conditions characterized by social deficit and repetitive behaviors. It is believed that peptides like BCM-7 might play a role in the development of autism. However, the studies on this relationship are not always displayed [62-64]. Kost et al. [37] have shown that breast feeding has an advantage over artificial feeding for infant's development during the first months of life and support the hypothesis for deterioration of bovine casomorphin elimination as a risk factor for delay in psychomotor development and other diseases such as autism. On the other hand, some authors have suggested that food peptides might be able to determine toxic effects at the level of the central nervous system by interacting with neurotransmitters. In fact a worsening of neurological symptoms has been reported in autistic patients after the consumption of milk and wheat [65]. That means that there was a close relationship between food allergy and infantile autism. In conclusion, it can be said that A1-milk has no significant effect on autism symptom compared to A2-milk and further investigations are necessary.

\subsection{Sudden death of infants}

Sudden infant death syndrome is the most common cause of death in infants under 12 months old and its pathogenesis is complex and multifactorial. Casein-derived peptides as BCM-7 have been suggested to play a role in sudden infant death syndrome. Sun et al. [66] described in a study the possible relationship between BCM-7 and sudden infant death syndrome. On the other hand, the studies by Wasilewska et al., [38] have shown that the sera of some infants after an apnoea event contained more BCM-7 than that of the healthy infants in the same age. These results indicate that some children may be sensitive to A1-milk. But more research is needed to get concrete results before any firm conclusions can be reached. 


\section{Conclusion}

Whether A2-milk is really healthier than A1-milk or not; farmers, breeders, societies and the media have been dealing with this for several years. The difference between the two milk variants is only a single amino acid deviation of beta casein. In the course of development, the A1-milk mutation has occurred at some point, because the A2-milk is considered the more natural form. A1-milk and the peptide BCM-7 may be linked to heart disease, diabetes, autism, sudden death of infants and inflammation in the digestive system. The results are mixed and further studies are needed.

\section{Reference}

[1] Muehlhoff E, Bennett A, McMahon D. Milk and dairy products in human nutrition. Food and Agriculture Organization of the United Nations, Rome. 2013.

[2] Regner A. Is “original milk” the better milk? The PTA in the Pharmacy. 2020(2):70-71. (in Germany).

[3] Frister H. Composition of the milk. In: Kroemker V. Milk Science and Milk Hygiene. Parey. 2007:80-102 (in Germany).

[4] Kaskous S. The effect of using quarter individual milking system "MultiLactor" on improvement of milk performance and milk quality of different dairy cows breeds in different farms. Emirates Journal of Food and Agriculture. 2018;30 (1):57-64.

[5] Kaskous S. Camel milk composition, udder health and effect of different storage times and temperatures on raw milk quality using camel milking machine "StimuLactor". Agriculture and Food Sciences Research. 2019;6(2):172-181.

[6] Galali Y, Al-Dmoor HM. Miraculous properties of camel milk and perspective of modern science. Journal of Family Medicine and Disease Prevention. 2019;5(1):095.

[7] Inhofer C. A2 milk also interesting for Bavarian cow farmers? LKV Journal for Animal Owners in Bavaria 2019;4:42-43 (in Germany).

[8] Arnarson A. A1 vs. A2 milk-Does it matter? 2019. www.healthline.com.

[9] EFSA Scientific report: Review of the potential health impact of $\beta$-casomorphins and related peptides. EFSA Scientific Report. 2009;231:1-107.

[10] Bekuma A, Galmessa U. A1 Beta casein: Devil in the milk-A short communication. Approaches in Poultry, Dairy \& Veterinary Sciences. 2019;7(1):606-608.

[11] Cieslinska A, Kaminski S, Kostryra E, Sienkiewicz-Szlapka E. Beta-casomorphin 7 in raw and hydrolyzed milk derived from cows of alternative beta-casein genotypes. Milchwissenschaft. 2007;62(2):125.

[12] Kaminski S, Cieslinska A, Kostyra E. Polymorphism of bovine beta-casein and its potential effect on human health. J. Appl. Genet. 2007;48(3):189-198.

[13] Stanton C, McMahon D, Mills S. Dairy components, products and human health. In: Muehlhoff et al., Milk and Dairy Products in Human Nutrition. Food and Agriculture Organization of the United Nations, Rome. 2013.

[14] Barth CA, Behnke U. Nutritional significance of whey and whey components. Nahrung. 1997;41(1):2-12.

[15] Kaskous S. Comparative studies on artificial lactation induction in young cattle aged 12 to 19 months under consideration the milk composition and the level of blood plasma concentration of 17 beta- estradiol, progesterone and prolactin. PHD thesis. Faculty of Veterinary medicine, Leipzig University, Leipzig, Germany. 1989. p. 60-80 (in Germany).

[16] Cavallo MG, Fava D, Monetini L, Barone F, Pozzilli P. Cell-mediated immune response to beta casein in recent-onset insulin-dependent diabetes: Implications for disease pathogenesis. Lancet. 1996;348 (9032):926928.

[17] Farrell HM, Jimenez-Flores R, Bleck GT, Brown EM, Butler JE, Creamer LK, Hicks CL, Hollar CM, NGKwai-Hang KF, Swaisgood HE. Nomenclature of the proteins of cow's milk-sixth revision. Journal Dairy Science. 2004;87:1641-1674.

[18] Aschaffenburg R. Inherited casein variants in cow's milk. Nature. 1961;192(4801):431-432.

[19] Peterson RF, Kopfler FC. Detection of new types of $\beta$-casein by polyacrylamide gel electrophoresis at acid pH: A proposed nomenclature. Bioch. and Biophys. Research Communications. 1966;22:368.

[20] Eigel WN, Butler JE, Ernstrom CA, Farrell HM, Halwarkar VR, Jenness R, Whitney RM. Nomenclature of proteins of cow's milk: fifth revision. Journal Dairy Science. 1984;67:1599-1631.

[21] Clemens RA. Milk A1 and A2 peptides and diabetes. In: Milk and Milk Products in Human Nutrition 2011 (Vol. 67, pp. 187-195). Karger Publishers.

[22] Clemens R, Pressman P. A1/A2 milk and $\beta$-Casomorphins: The Resurgence of controversy. Food Technology Magazine. 2018;72 (12):1-4. 
[23]Swinburn, B. Beta casein A1 and A2 in milk and human health. Report to New Zealand Food Safety Authority. 2004. https//pdfs.semanticscholar.org/459b.

[24] De Noni RJ, FitzGerald HJT, Korhonen Y, LeRoux CT, Livesey I, Thorsdottir D, Tome RW. Scientific report of EFSA prepared by a DATEX working group on the potential health impact of $\beta$-casomorphins and related peptides. Eur. Food Saf. Auth. 2009; 231: 1-107.

[25] Brooke-Taylor S, Dwyer K, Woodford K, Kost N. Systematic review of the gastrointestinal effects of A1 compared with A2 $\beta$-casein. Adv. Nutr. 2017;8:739-748.

[26] Elliott RB, Harris DP, Hill JP, Bibby NJ, Wasmuth HE. Type 1 (insulindependent) diabetes mellitus and cow milk: casein variant consumption. Diabetologia. 1999;42(3):292-296.

[27] Ng-Kwai-Hang KF, Grosclaude F. Genetic polymorphism of milk proteins. In: Fox PF, McSweeney PLH (eds). Advanced Dairy Chemistry: Volume 1: Proteins, Parts A. \& B. Kluwer Academic/Plenum Publishers: New York. 2002. p: 739-816.

[28] Dechow C. Is it time to select for A2 milk protein? 2016. https://hoards.com/article-19315-is-it-time-toselect-for-a2-milk-protein.html.

[29] A2 Milk \& Brown Swiss. www.brownswiss.org.

[30] Pal S, Woodford K, Kukuljan S, Ho S. Milk intolerance, beta-casein and lactose. Nutrients. 2015;7:72857297.

[31] De Noni I, Cattaneo S. Occurrence of $\beta$-casomorphins 5 and 7 in commercial dairy products and in their digests following in vitro simulated gastro-intestinal digestion. Food Chemistry. 2010;119 (2):560-566.

[32] Jinsmaa Y, Yoshikawa M. Enzymatic release of neocasomorphin and beta-casomorphin from bovine betacasein. Peptides. 1999;20: 957-962.

[33] De Noni I. Release of $\beta$-Casomorphins 5 and 7 during simulated gastro-intestinal digestion of bovine $\beta$-casein variants and milk-based infant formulas. Food Chemistry. 2008;110:897-903.

[34] Boutrou R, Gaudichon C, Dupont D, Jardin J, Airinei G, Marsset-Baglieri A, Benamouzig R, Tome D, Leonil J. Sequential release of milk protein-derived bioactive peptides in the jejunum in healthy humans. Am. J. Clin. Nutr. 2013;97(6):1314-1323.

[35] McLachlan CN. Beta-casein A1, ischaemic heart disease mortality, and other illnesses. Med. Hypotheses. 2001; 56(2): 262-272.

[36] Birgisdottir BE, Hill JP, Thorsson AV, Thorsdottir I. Lower consumption of cow milk protein A1 beta-casein at 2 years of age, rather than consumption among 11-to 14-year-old adolescents, may explain the lower incidence of type 1 diabetes in Iceland than in Scandinavia. Ann. Nutr. Metab. 2006;50(3):177-183.

[37] Kost NV, Sokolov OY, Kurasova OB, Dmitriev AD, Tarakanova JN, Gabaeva MV, Zolotarev YA, Dadayan AK, Grachev SA, Kroneeva EV, Mikheeva IG, Zozulya A.A. Beta-casomorphins-7 in infants on different type of feeding and different levels of psychomotor development. Peptides. 2009;30(10):1854-1860.

[38] Wasilewska J, Sienkiewicz-Szlapka E, Kuzbida E, Jarmolowska B, Kaczmarski M, Kostyra E. The exogenous opioid peptides and DPPIV serum activity in infants with apnoea expressed as apparent life threatening events (ALTE). Neuropeptides. 2011;45(3):189-195

[39] Teschemacher H, Umbach M, Hamel U, Praetorius K, Ahnert-Hilger G, Brantl V, Lottspeich F, Henschen A. No evidence for the presence of Beta-casomorphins in human plasma after ingestion of cow's milk or milk products. Journal Dairy Research.1986;53(1):135-138.

[40] Chowdhury R, Sinha B, Sankar MJ, Taneja S, Bhandari N, Rollins N, Bahl R, Martines J. Breastfeeding and maternal health outcomes: A systematic review and meta-analysis. Acta Paediatr. 2015;104:96-113.

[41] Chia JSJ, McRae JL, Enjapoori AK, Lefevre CM, Kukuljan S, Dwyer KM. Dietary cow’s milk protein A1 beta-casein increases the incidence of T1D in NOD Mice. Nutrients. 2018;10:1291.

[42] Chia JSJ, McRae JL, Kukuljan S, Woodford K, Elliott RB, Swinburn B, Dwyer KM. A1 beta-casein milk protein and other environmental pre-disposing factors for type 1 diabetes. Nutr. Diabetes. 2017; 7: e274.

[43] Lamb MM, Miller M, Seifert JA, Frederiksen B, Kroehl M, Rewers M, Norris JM. The effect of childhood cow's milk intake and HLA-DR genotype on risk of islet autoimmunity and type 1 diabetes: The diabetes autoimmunity study in the young. Pediatr. Diabetes. 2015;16:31-38.

[44] Laugesen M, Elliott R. Ischaemic heart disease, type 1 diabetes, and cow milk A1 beta-casein. N. Zeal. Med. J. 2003;116(1168):U295.

[45] Milan AM, Shrestha A, Karlström HJ, Martinsson JA, Nilsson NJ, Perry JK, Day L, Barnett MP, CameronSmith D. Comparison of the impact of bovine milk $\beta$-casein variants on digestive comfort in females selfreporting dairy intolerance: a randomized controlled trial. The American Journal of Clinical Nutrition. 2020;111(1):149-160.

[46] Beales PE, Elliott RB, Flohe S, Hill JP, Kolb H, Pozzilli P, Wang GS, Wasmuth H, Scott FW. A multi-centre, blinded international trial of the effect of $\mathrm{A}^{1}$ and $\mathrm{A}^{2} \beta$-casein variants on diabetes incidence in two rodent models of spontaneous type 1 diabetes. Diabetologia. 2002;45(9):1240-1246. 
[47] Yin H, Miao J, Zhang Y. Protective effect of $\beta$-casomorphin-7 on type 1 diabetes rats induced with streptozotocin. Peptides. 2010;31(9):1725-1729.

[48] Yin H, Miao J, Sun G, Zhang Y. $\beta$-casomorphin-7 cause decreasing in oxidative stress and inhibiting NF-kBiNOS-No signal pathway in pancreas of diabetes rats. Journal Food Sci. 2012;77(2): C278-C282.

[49] Venn BJ, Skeaff CM, Brown R, Mann JI, Green TJ. A comparison of the effects of A1 and A2 beta-casein protein variants on blood cholesterol concentrations in New Zealand adults. Atherosclerosis. 2006;188 (1):175-178

[50] Chin-Dusting J, Shennan J, Jones E, Williams C, Kingwell B, Dart A. Effect of dietary supplementation with beta-casein A1 or A2 on markers of disease development in individuals at high risk of cardiovascular disease. Br. J. Nutr. 2006; 95(1): 136-144.

[51] Ho S, Woodford K, Kukuljan S, Pal S. Comparative effects of A1 versus A2 beta-casein on gastrointestinal measures: a blinded randomized cross-over pilot study. European Journal of Clinical Nutrition. 2014;68(9):994-1000.

[52] He M, Sun J, Jiang ZQ, Yang YX. Effects of cow’s milk beta-casein variants on symptoms of milk intolerance in Chinese adults: a multicenter, randomized controlled study. Nutrition Journal. 2017;16:72-84.

[53] Defilippi C, Gomez E, Charlin V, Silva C. Inhibition of small intestinal motility by casein: a role of beta casomorphins? Nutrition. 1995;11:751-754.

[54] Daher S, Tahan S, Sole D, Naspitz CK, Da Silva Patricio FR, Neto UF, De Morais MB. Cow’s milk protein intolerance and chronic constipation in children. Pediatr Allergy Immunol. 2001;12:339-342.

[55] Andiran F, Day S, Mete E. Cow's milk consumption in constipation and anal fissure in infants and young children. Journal Paediatrics and Child Health. 2003;39:329-331.

[56] Barnett MPG, McNabb WC, Roy NC, Woodford KB, Clarke A.J. Dietary A1 $\beta$-casein affects gastrointestinal transit time, dipeptidyl peptidase- 4 activity, and inflammatory status relative to A2 $\beta$-casein in Wistar rats. International Journal of Food Sciences and Nutrition. 2014;65(6):720-727.

[57] Jianqin S, Leiming XU, Xia Lu Gregory WY, Jiayi NI, Clarke A.J. Effects of milk containing only A2 beta casein versus milk containing both A1 and A2 beta casein proteins on gastrointestinal physiology, symptoms of discomfort, and cognitive behavior of people with self-reported intolerance to traditional cow's milk. Nutrition Journal. 2016;15:35-51.

[58] Haq MR, Kapila R, Sharma R, Saliganti V, Kapila S. Comparative evaluation of cow $\beta$-casein variants (A1/A2) consumption on Th2-mediated inflammatory response in mouse gut. European Journal Nutrition. 2013;53:1039-1049.

[59] Becker A, Hempel G, Grecksch G, Matthies H. Effects of beta-casomorphin derivatives on gastrointestinal transit in mice. Biomed Biochim Acta. 1990;49:1203-1207

[60] Daniel H, Vohwinkel M, Rehner G. Effect of casein and beta-casomorphins on gastrointestinal motility in rats. Journal Nutrition. 1990;120: 252-257.

[61] Mihatsch WA, Franz AR, Kuhnt B, Hogel J, Pohlandt F. Hydrolysis of casein accelerates gastrointestinal transit via reduction of opioid receptor agonists released from casein in rats. Biol. Neonate. 2005;87:160-163.

[62] Reichelt KL, Knivsberg AM. Can the pathophysiology of autism be explained by the nature of the discovered urine peptides? Nutr. Neurosci. 2003;6(1):19-28.

[63] Hunter LC, OHare A, Herron WJ, Fisher LA, Jones G.E. Opioid peptides and dipeptidyl peptidase in autism. Dev. Med. Child Neurol. 2003;45(2):121-128.

[64] Cass H, Gringras P, March J, McKendrick I, OHare AE, Owen L, Pollin C. Absence of urinary opioid peptides in children with autism. Arch. Dis. Child. 2008;93(9):745-750.

[65] Lucarelli S, Frediani T, Zingoni AM, Ferruzzi F, Giardini O, Quintieri F, Barbato M, D’Eufemia P, Cardi E. Food allergy and infantile autism. Panminerva Med. 1995;37(3):137-141.

[66] Sun Z, Zhang Z, Wang X, Cade R, Elmir Z, Fregly M. Relation of beta-casomorphin to apnea in sudden infant death syndrome. Peptides. 2003;24(6):937-943.

(C) 2020 by the author(s). This work is licensed under a Creative Commons Attribution 4.0 International License (http://creativecommons.org/licenses/by/4.0/). Authors retain copyright of their work, with first publication rights granted to Tech Reviews Ltd. 